\title{
Integrated Supply Chain Management Practices in the Flow Information Toyota Car Dealer in Kendari
}

\author{
La Hatani \\ Department of Management, Faculty of Economics and Business, Halu Oleo University, Indonesia
}

\begin{abstract}
-ABSTRACT-
Supply chain management is the company's efforts to increase competitiveness, through reduced operating costs, improved inventory, decisions regarding the flow of information, customer satisfaction and in which there are networks of companies ranging from suppliers, distributors, agents and consumers. This study aims to explain the integrated Supply Chain Management practices in the information flow of Toyota car dealer in Kendari City. Informants in this study are administration department manager, supervisor, and salesman Toyota car dealer in Kendari City. Data collection methods used was interviews and the Literature Review, Analysis of the data used is descriptive qualitative analysis. The study states that the implementation of integrated supply chain management in times like these fit applied, because this system has advantages wherein capable of regulating the flow of information in a supply chain.
\end{abstract}

Keywords: Supply Chain Management, Flow Information.

Date of Submission: 28 December $2016 \longrightarrow$ Date of Accepted: 10 January 2017

\section{INTRODUCTION}

The successful integration of the supply chain can establish effective coordination in the processes of supply chain information flow that never faltered from the upstream and downstream supply chain. The integration of the supply chain to make each member of the supply chain has visibility in capacity and supplies other members of the supply chain in order to assist with planning and scheduling. Supply chain integration is an effective coordination between supply chain processes through continuous information flow from the upstream to downstream. The integration of the supply chain involves a process of internal and external supply chain processes should be developed through the integration of suppliers, companies and consumers or internal and external integration can be achieved through standardization of sustainable of any logistics functions with the distribution of efficient information and linkages between suppliers, companies and customers.

The development of increasingly fierce market competition today, Toyota car still able to maintain the strength of its market share. In the last three years, Toyota car positions could not be rivaled by any other car manufacturer. In the first quarter of 2015 was Toyota car still top position in the ranks of the global automotive industry. In the first three months period of this year, Toyota car was able to sell 2.53 million units globally. With these sales figures, Toyota car was able to strengthen its position in the global automotive world.

Hadji Kalla is the main distributor of Toyota brand cars for the marketing area of South Sulawesi, Southeast Sulawesi and Central Sulawesi. Until recently was one of the dealers of Toyota Astra Motor, located in Jakarta. Hadji Kalla until now has had branches in marketing the car brands Toyota, Branch Kendari is one of them. Although Toyota car products is a global product that has the most sales for its class, but there are problems experienced company before the car reached the hands of consumers his specialty in Kendari City.

Demand for Toyota cars is quite high in the market, sometimes Hadji Kalla Kendari constrained to prepare and serve consumer demand in a timely manner, this problems which makes researchers interested in conducting further research based on the concept of supply chain management integration. The researchers' goal is to explain the practices of supply chain management activities are integrated in the flow of information Toyota car dealer in Kendari City in the review of aspects of coordination, cooperation, and collaboration in terms of both internal and external.

\section{REVIEW LITERATUR}

Supply chain management (SCM) was first proposed by (Oliver and Weber, 1982; Lembert et al., 1998). Supply chain but was first implemented by multiple logistic consultants around the 1980s, then the experts academics analyzed further in the 1990s. According Pujawan (2005), the supply chain is a network of companies that together work to create and deliver a product to the final hand. These companies typically include suppliers, manufacturers, distributors, store or retail, as well as corporate support such as logistics Services Company. 
Supply Chain Management includes product development, purchasing (procurement), planning and control, operations or production, and delivery or distribution.

Good SCM can enhance the ability to compete for the supply chain as a whole, but does not cause the party to sacrifice long-term (Pujawan, 2005). So, we need mutual understanding, trust, and clear rules. For example, when a company wants to share information in a transparent manner, partner companies must keep such information from the parties that could misuse. It's important to maintain ethics for those who want a strong supply chain in the long term Pujawan (2005). Ideally, the relationship between the parties to an ongoing longterm supply chain. Long-term relationship enables all parties to create a better trust and create efficiencies. Efficiency can be created because of a long term relationship which can reduce the cost to get a new partner company. However, it should be observed that the long-term orientation in the context of the supply chain on empirical conditions must still be interpreted flexibly.

SCM principle is essentially the synchronization and coordination of activities related to the flow of the product, both the organization and between organizations, all of which must be integrated in terms of synchronization SCM by Krajewski et al. (2010). The three main reasons for implementing supply chain management, namely: (1) reduce investment throughout the supply chain; (2) improve service to consumers; and (3) develop excellence competition companies (Anatan and Ellitan, 2008). Kwai-Sang et al. (2004) suggests there are five important reasons why supply chain management needs to be implemented, namely: (1) reducing operating costs, (2) improving inventory, (3) reduce the wait time delivery, (4) improve customer satisfaction, and (5) reduced competition

The American professional associations express purpose of supply chain management is the management of the supply chain include: planning and management of all management activities involved in sourcing and procurement, conversion, and logistics activities include the coordination and cooperation with distribution partners, suppliers, intermediaries, third party service providers and customers. Supply chain management includes activities to determine: (1) transport to the vendor, (2) transfer of money on credit and cash, (3) suppliers, (4) banks and distributors, (5) debt and receivables, (6) warehousing and inventory levels, (7) order fulfillment, (8) share information to customers, estimates and production. The goal is to build a supply chain that is focused on maximizing value for customers by Haizer and Render (2010). The activity of the managers of the supply chain covers the science of accounting, finance, marketing and operations.

Starting from an integrative philosophy that in order to manage the flow of material and information originated from the supplier to the customer, and including activity final settlement process, the integrative supply chain include the coordination, collaboration and cooperation across functions within the enterprise and across the supply chain. Therefore, it requires internal integration (intraorganizational) and external (interorganizational) by (Gimenez and Ventura, 2005; Soo Kim, 2006a; Ting Chi, 2009; Jiqin Han et al., 2009; Hussain and Othman, 2010; Vijay and Tan 2010; Pamela and Romano, 2011).

Internal integration of the supply chain is an activity that emphasizes the flow of material and information that is carried in the functional areas of the production department, purchasing, inventory management, packaging, warehousing, sales, transportation and distribution departments through coordination, collaboration and cooperation between cross-functions under the control of the company (Flynn et al., 2010; Sakun and Wong, 2011). Measurement of internal integration can be known through the supply chain management activities and information with other functions in the field of each company. Indicators measuring internal integration include: internal coordination, cooperation and collaboration internal supply chain between functions within the company (Gustavo Vargas, et al., 2000; Gimenez and Ventura, 2005; Soo Kim, 2006a; Jiqin Han et al., 2009; Vijay and Tan, 2010; Sakun and Wong, 2011).

Krajewski et al. (2010) suggested the integration of external supply chain is an effective coordination between the processes in the supply chain through the flow of information, materials and sustainable cash flow to suppliers and customers. Measurements construct integration of external supply chain in this study did not assess the global level of external integration companies there is a need to examine the integration on each part of the supply chain, but more focused on the integration to suppliers and customers are measured through indicators: external coordination, external collaboration and cooperation external supply chain (Gustavo et al., 2000; Gimenez and Ventura, 2005; Soo Kim, 2006a; Hussain and Othman, 2010; Sakun and Wong, 2011).

\section{RESEARCH METHODS}

The object of research is Toyota car dealer of Hadji Kalla in Kendari City, which is a company engaged in the Toyota car dealership. Data used this research is the primary data includes data related to variable statement of informant this study is the integration of external and internal integration. Primary data is obtained or derived from key an informant (leader/ manager) who has a deep knowledge of the study of this research through indepth interviews. Methods of data collection of this research are: (1) review of the literature, a collection of data by way of literature is to do a study and have to theories that are relevant to the measurement of the variables in 
this study, (2) in-depth interviews, the technique is used to support and reveal the facts behind the findings of the quantitative analysis. Interviews were conducted in more detail by the researchers after analyzing the data of some of the respondents who are considered able to provide explanations on the substance of this research study. The method in data collection by using the technique of in-depth interviews. Creswell and Clark (2011), the data from the information obtained from in-depth interviews (in-depth interviews) using two ways: open-closed interviews and documentation of the interviews. This study was conducted in-depth interviews to explain the results of the research findings. Informants who are willing to take the time to be interviewed through in-depth interviews with researchers till the end of the discussion of this study. This is done in order to test the validity of the source triangulation. The results of interviews with informants recorded by investigators and informants contacted by telephone if there are less obvious from the interview. Facts on the ground that we want to know from the research are expected to support the study was not included in the questionnaire asked also by researchers in the interview.

\section{RESULTS AND DISCUSSION}

Informants in this study as many as 3 are composed of administrative leadership, Supervisor, and Salesman. Supervisor aged less than 42 years old at the time of the interview, followed by administration leaders were aged less than 38 years, and the salesman were aged less than 29 years. Informants in this study male sex. Atmosphere at the time investigators interviewed the informant was in an atmosphere of formality.

\section{Flow of Information Supply Chain Management}

This research is a survey, which is a description of the object information based on observations and planned to obtain data with observations of the ongoing activities, where information can be obtained at PT. Toyota Hadji Kalla Kendari Toyota products. The flow of information or also known as the distribution of information is the process by which the right information is delivered to the right person, at the desired time. Distributions of information within the organization are ways to get information and share information.

The concept of supply chain management is relatively new, is actually an extension or development of logistics concepts. Only logistics management is more focused on setting the flow of goods in the supply chain management while the company considers that internal integration is not enough. Stevens (1989) quoted Gimenez and Ventura (2005) that the company's relative should be able to achieve a high degree in the internal integration (cooperation and coordination between internal processes) and external (cooperation and coordination with suppliers and customers) after applying supply chain management. According to the Theory of Evolution Logistics proposed by Gimenez and Ventura (2005) the distribution of information that is implemented for Toyota cars are as follows:

The information available at this time for the car manufacturer Toyota has different manufacturers. For cars like ethos Varco, Fortuner and Innova in rafts by the manufacturer Toyota motor manufacturing Indonesia is located in an industrial area Karawang western java. Toyota Avanza, Agya, and Rush on the raft by the manufacturer Daihatsu located in Sunter, north Jakarta. Avanza and Xenia is the twin brother as Agya and Ayla or Rush and Terios which is in production at the same roof but with different sales prices. The manufacturer Daihatsu under the auspices Astra International Tbk work together to sell cars Avanza to Toyota Astra Motor Tbk, but cars Toyota can be modified either interior capable the exterior, so the car Toyota look more attractive compared twin brother even though they were in production in the same factory. Information also mentions that the car Toyota Yaris and Hilux Toyota in production by the manufacturer in Indonesia, with these cost-saving measures such as the transport of the Toyota factory in Thailand will be reduced because the Indonesian manufacturer only supplies spare parts or raw materials for the raft in the country.

The success of the supply chain in Toyota Hadji Kalla highly dependent on information systems across its divisions, with the cooperation of business information in the supply chain can be calculated. Lack of coordination of the parties involved in the supply chain will lead to distortion of information. Information sharing is the intensity and capacity of the company in its interaction to share information relating to partner with business strategies together. Information sharing also allows members of the supply chain to obtain, maintain, and deliver the information needed to ensure effective decision making widened, and is a factor that is able to strengthen elements of the overall collaboration therefore congestion can be reduced in the presence of industry information sharing.

\section{Internal Integration Supply Chain}

Based on the theory stated by Heizer and Render (2008) that Supply chain management is the integration of activities of the procurement of materials and services, conversion into semi-finished goods and finished products, as well as delivery to the customer. Supply chain management needs to consider that all activities 
ranging from suppliers, manufacturers, warehouses, distributors, retailers, until the retailer to have an impact on the cost of products manufactured in accordance with customer needs.

Logistics is referred to as a fixed current limit; the progress of logistics has become the main source of a company to generate new profits. Also, there are several examples where the logistics system has become the cause of inhibiting an overall management. The ability to reduce total costs and to improve the quality of services provided to consumers can be increased through the elimination of these Barriers. In order to support the flow of transparent information on the entire chain involved in SCM commitment required (can be achieved through partnerships and agreements) is accompanied by database availability.

\section{Internal supply chain coordination}

Team work between divisions has been carried out within the Company Toyota Hadji Kalla Kendari, parts division Salesman offer and sell cars Toyota to consumers and then when consumers do purchase one of the cars Toyota then do check in warehouse inventories Toyota Hadji Kalla Kendari for reservations or Toyota car purchase consumer must pay a 30\% mark so that the car can be in the order process and if through the Finance then there must be a prior approval. If the car is customer orders in a state of low or the stock is empty, the parts warehouse inventory to report on the logistics division to be in sync on the leadership of the administration to the completeness of the report request to Toyota Hadji Kalla in Makassar, in because Toyota Hadji Kalla Kendari just an offshoot of Toyota Hadji Kalla in Makassar.

Interviews from informants about internal integration regarding the internal coordination of the supply chain can be deduced that:

1) Importance of the formation of work teams between divisions in the management of logistics enterprises must be achieved for the company, especially PT. Toyota Hadji Kalla Kendari or a company that is on the network throughout the supply chain management and procurement chain.

2) The importance of sharing related to logistics management activities of the company, because sharing is used as the basis in making decisions that must be acquired at the right time, quickly, and have good quality. Information is the basis for the implementation of supply chain processes.

3) The importance of teamwork in the workplace management activities of the company, due to its compactness along with a company does not have barriers in their business processes, with such, compactness can eliminate the barriers and other obstacles that arise. That's why we have to have the compactness of the work.

\section{Internal Supply Chain Cooperation}

Build an integrated information system of cooperation based on the existing order is more of a journey than a destination, especially for management who are not familiar with the technology infrastructure in the company. The main task of managing the company's relationship with customers and prospects. For new customers, facilities usually provided a quick and easy registration. Integrated Planning in the firm made between all the divisions as an example that is given by the informant, during Ramadan Toyota car sales will increase by about $30 \%$, before it happens cooperation of the Toyota Hadji Kalla Kendari and Makassar is to determine how customer orders can be quickly and accurately.

Integrated planning is not only done by one division, but involves the entire division, when the forecast sales of the case that is given by the informant is correct then sync between divisions warehousing, logistics, and administration must be precisely and quickly respond to and report to the central office. But if the forecast is rather bolted and problems arise, the joint responsibility to overcome these problems. The results of interviews with informants about internal cooperation in the supply chain can be deduced that:

1) Preparation of integrated planning to anticipate logistical problems within the company, planning is the incorporation of parts or activities to form a whole, integrated planning can improve the relationship each value chain, facilitating decision making, allowing the creation of value and the transfer process from supplier to end customer to operate the flow of information, knowledge, equipment, and physical assets.

2) Establish common goals in the management of logistics companies, to get good results through a cooperation, a good relationship between both parties is absolutely necessary in terms of setting goals to be achieved, due to the shared goal setting different opinions will be resolved.

3) Building a common understanding of the responsibilities given, the objective of supply chain management is to ensure the unity of movement of the quantity and adequate quality in inventory that includes many things such as planning and communication through understanding and responsibility given, more simply mean that the purpose of supply chain management is to ensure that all items of goods that are in place and the right time in order to provide the best benefits and services to consumers. 
Integrated Supply Chain Management Practices In The Flow Information Toyota Car Dealer...

\section{Internal Supply Chain Collaboration}

Collaboration can regulate the flow of goods in total strategy. Thus, the total logistics optimization not only is resolved from the standpoint of the company, and therefore, the total optimization of the flow of goods including required in the company's supply chain. When trying to optimize the total flow in the supply chain, should be explained that the company's profits in the supply may be at odds due to the partial distribution of costs and benefits among the Company. Thus, the collaboration between the earnings of a company is indispensable in logistics management in SCM. They also have different abilities or competencies that complement each other and it is necessary for further coordination. For example, collaboration is required among companies in the areas of planning, production and transportation. In fact it is not easy to coordinate some of the companies that have different profiles. If one would synchronize their products, they have to share the production schedule and coordinate transportation between factories. Information sharing is the foundation of supply chain integration, decisions on the level of integration is closely related to the decision on what information should be shared and how that information should be exchanged. Design configuration of the supply chain not only predict with whom the company must collaborate or integrate but also designing how the activities of companies related or connected to the same activity from another company (partner) and determine what information can and should be accessed by the partner.

Information will be undertaken by the Chairman of the Toyota Hadji Kalla Kendari against a policy and the flow of information about items in the company's Toyota Hadji Kalla Kendari is through the Head of Administration, then head of logistics, then the cellarer, and ends at the Supervisor and vice versa in connection with information regarding the stock of goods, sales, etc. Synchronization and the ability to make a collective agreement adopted by all divisions within the Toyota Hadji Kalla Kendari. Tackling the risks together also done in terms of the logistics of goods. In the process of delivery of goods typically vulnerable to the scratched, or damage to goods, where the synchronization decision is made. Warehousing division to check the amount of goods and damage to goods then do the process of determining whether the goods are worth selling or not the decision of operational standards damage to the goods (car). The next in doing administrative complaint process complaint to Toyota Hadji Kalla in Makassar and immediately take the next step in accordance with the direction of the central office of the Toyota Hadji Kalla Makassar

Risks in corporate responsibility not only in terms of delivery only, but could also be due to changes in customer orders, for example the color, type of car, etc. When inventory allows then there is no problem in it but if the inventory is empty then the consumer has the option to continue the order or postpone it temporarily until the goods are available and can be order in the process. Synchronizing a joint decision at this time is in need because of the risk and harm in it. When the order is changed, the cost of storage and maintenance of cars will certainly increase because it will increase the supply of cars in the warehouse. Things like this proper information needed and stored at the right time so that the company can reduce the risk. The results of interviews with informants about internal collaboration in the supply chain can be deduced that:

1) Ability of managers to make sharing of information on the activities of logistics management, supply chain success is dependent upon its information systems, the lack of information in the supply chain business cooperation can be taken into account, so that the company's managers must often make sharing with their parent companies.

2) Ability to make a deal to tackle the risks involved in logistics management activities of the company, a company specially PT. Toyota Hadji Kalla Kendari who have logistical know how to coordinate economic resources, and can provide an opportunity to make some considerations and the ability to make a deal to tackle the problems that exist in a company.

3) Ability to implement joint decisions synchronization within a company. In this case the application synchronization joint decisions in the future as this suited applied, because this system has advantages which were able to manage the flow of goods or products in a supply chain. In this case, applying the SCM models of how a network of production and distribution activities of an enterprise can work together to meet the demands of consumers.

\section{External Integration Supply Chain}

The companies several areas in developing countries, including Indonesia, are still very limited. Where the relationship between each sub-system involved in general is still discontinuous, making it difficult to compete in the free market. It can be seen between the sub systems upstream to the sub-system downstream caused by subsystem many played by entrepreneurs in the production scale is small, and does not have a strong bargaining position, and therefore indispensable formation of a work team with an outside company that is growing at currently. Hadji Kalla Toyota is a Toyota car distributor for the region, especially Sulawesi South Sulawesi, Central Sulawesi, West Sulawesi and Southeast Sulawesi. Toyota Astra Motor has the right brand of one - the only one in Indonesia for Toyota cars. Synchronization Toyota Hadji Kalla with suppliers, namely Toyota Astra 
Motor is needed to ensure stock availability of goods that will affect also coordination between the central office that Hadji Kalla Makassar with branches namely in Southeast Sulawesi, namely Toyota Hadji Kalla Kendari.

\section{External Supply Chain Coordination}

Synchronization decisions and ideas are also in need because Toyota Hadji Kalla has its own right to determine the selling price of the car and decisions about the company's marketing development ideas, while we can know that in Sulawesi's not just Hadji Kalla being the distributor of Toyota cars agencies, there Ratna Jaya Motor which is the delivery agent for the area North Sulawesi and Gorontalo.

Agency coordination with other suppliers can also provide advantages because if the stock availability consumables or insufficient, Hadji Kalla Toyota can do demand supply cars to other agencies if their car works pretty much inventory, but must be with the approval of Toyota Astra Motor since he was a Toyota trademark rights holder. Coordination of information on complaints and consumer opinion is also done to improve the image and the image of the company in the quality of consumer services such as promotion by purchasing a car has a car interior accessories bonus, there is also a free service of insurance for one year and so on. The results of interviews with informants on external coordination in the supply chain can be deduced that:

1) The importance of the formation of work teams in a company is important, because if we are coordinating with overseas companies then we will know how the strategy which we do not know.

2) The importance of sharing ideas with suppliers and customers, with the sharing of ideas accepted by the company, especially Toyota Hadji Kalla Kendari can provide the brightest minds to develop products that exist in a company's.

3) The importance of teamwork working with suppliers and customers, the importance of cohesiveness suppliers and customers is necessary, because the compactness of the long-term relationship as the perception of the interdependence of buyers to suppliers both in the context of a product or a relationship which is expected to bring benefits to the buyer in the long term.

\section{External Supply Chain Cooperation}

Before building the commitment and implement the 'contract of employment' with suppliers, the company must first implement supplier evaluation. If the supplier evaluation performed for the same material can be obtained more than one alternative suppliers. At least three criteria in evaluating suppliers, namely: the general state of the supplier, state services, and state of the material. Supply chain is not complete, the focus is often only on internal operations only. To overcome these challenges, first the company must make improvements and build commitment in the company's internal environment, and then build partnerships and commitments with the other chains in the external environment. One thing that is also important in addressing the challenges to the implementation of SCM is to manage information in a system that must support the decision-making process in the implementation of SCM. Cooperation Toyota Hadji Kalla with suppliers, namely Toyota Astra Motor improved by making reports integrated planning and synchronization decisions on Supply Toyota. Hadji Kalla Toyota Center make decisions about planning synchronization supply cars with Toyota Hadji Kalla Kendari. Upstream and downstream cooperation Hadji Kalla Toyota Kendari marked with the cooperation with the finance and insurance. Orientation Hadji Kalla satisfy the needs of consumers on the mark with their cooperation to facilitate the desire of consumers to buy a car with installment process so as not to burden and facilitate consumers in making car purchases. Marketing programs Toyota Hadji Kalla Kendari related to customer satisfaction involve cooperation with insurance that would benefit both sides, the car Toyota that was purchased by the consumer will get free insurance up to the specified time, and the company certainly pays a premium to the price of low appeal to companies More to the insurance company for mutually beneficial cooperation between the two sides. The results of interviews with informants on the external supply chain collaboration as follows:

1) Make integrated planning to anticipate logistical problems with suppliers and customers, the planning done by the company with the customer is very well done, because by doing cooperation in terms of planning can make the company especially Toyota Hadji Kalla Kendari know what the shortcomings and weaknesses of these companies, so the company can improve and overcome these weaknesses.

2) Setting goals together with our customers and suppliers, setting goals shared between the company and customers is a good thing, because the customer can complain to the company any chill of the company's products, company with customers can achieve the goals to be cool without any problems that happened.

3) Building a common understanding with the supplier's customers as well, with a good understanding between the parties can customer creating a company with a good collaborative relationship, because understanding between the company and the customer is required to create a product that still results unfavorable risk. 


\section{External Supply Chain Collaboration}

The relationship between suppliers and producers should be healthy and maintained, because the company's level of dependence on suppliers is very high, long-term, due to both large companies and small companies always perform logistics activities. That requires a supply chain that is integrated properly so as to increase the competitive advantage of the product produced. Information is a set of data that has been grouped, processed, and communicated to the needs of sensible and meaningful or useful. Therefore the information used as a basis to make decisions that must be acquired at the right time, quickly, and have good quality. Information is the basis for the implementation of supply chain processes. Sharing information on the logistics company with Toyota Hadji Kalla with Toyota Astra Motor as suppliers in doing so PT. Toyota Astra Motor also synchronize on the company car manufacturer Daihatsu Toyota either from the manufacturer or manufacturer Toyota.

Sharing is also done to loyal customers of Toyota cars for example as a free service to and fro in the end season last year. Information can also make consumers feel comfortable, because the consumer can determine the extent of the booking process they can be accessed by directly asking the customer service or Toyota call center. The results of interviews with informants about external collaboration Supply Chain can be deduced as follows:

1) The ability to share information with suppliers and customers, sharing with customers is needed to not happen uncertainty of the environment, the facilitator of intra-organizational and inter-organizational and sharing can help companies to improve the efficiency and effectiveness of the supply chain and is the most important factor for achieving coordination that is effective in controlling the supply chain and throughout the supply chain.

2) Ability to make a deal together suppliers and customers, making a collective agreement between the company and the customer is very good, because the agreement made between the two sides can reach a goal to be achieved and equally benefit the company and customers.

3) The ability to synchronize the joint decision of both suppliers and customers, synchronizing shared decision also is in need for a joint decision can be used and distributed along the supply chain. Therefore, understanding the factors that influence the joint decision between the company and the customer is in need for quality support and information-sharing.

\section{CONCLUSION}

Based on the problems that have been raised, the writer can draw some conclusions with regard to research and discussion, namely: (1) the Supply Chain Management integration in the enterprise will be possible to increase the effectiveness and efficiency in the process of setting inventory, customer order fulfillment as well as the distribution of finished goods. Implementation of supply chain management in times like these fit applied, because this system has advantages wherein capable of regulating the flow of goods or products in a supply chain, and (2) The Information Synchronization in aspects of coordination, cooperation, and collaboration both in terms of internal and external will provide benefits, knowledge, ideas - new ideas that will make the company become more innovative.

\section{REFERENCES}

[1]. M Ozaki, Y. Adachi, Y. Iwahori, and N. Ishii, Application of fuzzy theory to writer recognition of Chinese characters, International Journal of Modelling and Simulation, 18(2), 1998, 112-116.

[2]. Candace Y. Yi, E.W.T. Ngai and K-L. Moon (2011), "Supply chain flexibility in an uncertain environment: Exploratory findings from five case studies". Supply Chain Management: An International Journal, Vol. 16 No. 4, pp. 271-283.

[3]. Creswell J. W. (2011). Research Design Qualitative, Quantitative, and Mixed Methods Approaches. (3th ed.). Sage, Los Angles.

[4]. David Xiaosong Peng; Roger G. Schroeder and Rachna Shah (2011), "Competitive priorities, plant improvement and innovation capabilities, and operational performance A test of two forms of fit", International Journal of Operations Management, Vol. 31No. 5, pp. 484-510.

[5]. Flynn, B.B., Huo, B. and Zhao, X. (2010), "The impact of supply chain integration on performance: a contingency and configuration approach", Journal of Operations Management, Vol. 28 No.1, pp. 58-71.

[6]. Frank Wiengarten; Brian Fynes and Alan McKittrick, (2010), "Collaborative Supply Chain Practices and Performance: Exploring The Key Role Of Information Quality”, Supply Chain Management: An International Journal, Vol. 15 No. 6, pp. 463-473

[7]. Fynes, B., de Burca, S. and Voss, C., (2005), "Supply chain relationship quality, the competitive environment and performance", International Journal of Production Research, Vol. 43 No. 16, pp. 03-20.

[8]. Gimenez, C. \& Ventura, E. (2005), "Logistic-Production, Logistic-Marketing and External Integration Their Impact on Performance, Emerald International Journal of Operations \& Production Management, Vol. 25 No. 1, pp. 20-38.

[9]. Heizer. J and Render B, (2010), "Operations Management (Manajemen Operasi)”, Edisi 9 Penerbit Salemba Empat. Jakarta

[10]. Hussain A.H Awad and Mohammad Othman Nassar, (2010), "Supply Chain Integration: Definition and Challenges", Proceedings of the IMECS, Vol. 1 No. 1, pp. 1-5.

[11]. Jiqin Han, Jacques H. Trienekens, and S.W.F. Omta (2009), "Integrated information and logistics management, quality management and firm performance of pork processing industry in China" British Food Journal, Vol. 111 No. 1, 2009 pp. 9-25

[12]. Kamel Aissa Fantazy, Vinod Kumar and Uma Kumar (2009), "An empirical study of the relationships among strategy, flexibility, and performance in the supply chain context", Supply Chain Management: an International Journal, Vol. 14 No. 3, pp. 177-188.

[13]. Krawjeski L.J, Rizmant L.P, and Malhotra M, K (2010), “Operation Managemen, Processes and Supply Chains", (9th ed.). Pearson Education, New York, NY. 
[14]. Li, S.H., Rao, S.S., Nathan, R.T. and Nathan, B.R. (2006), "The impact of supply chain management practices on competitive advantage and organizational performance", Omega, Vol. 34 No.1, pp. 107-24.

[15]. Lina Anatan and Lena Elitan, (2008), "Supply Chain Management Theory and Applications ", Publisher Alfabeta, Bandung.

[16]. Pamela Danese and Pietro Romano, (2011), "Supply Chain Integration and Efficiency Performance: A Study on the Interactions between Customer and Supplier Integration", Supply Chain Management: An International Journal, Vol. 16 No. 4, pp. 220-230.

[17]. Pujawan (2004), "Assessing Supply Chain Flexibility: A Conceptual Famework \& Case Study", Int. J. Integrated Supply Management, Vol. 1 No. 1, pp. 79-97.

[18]. Pujawan 2005, "Supply Chain Management", Guna Widya, Surabaya.

[19]. Quah Hock Soon and Zulkifli Mohamed Udin (2011), "Supply chain management from the perspective of value chain flexibility: an exploratory study", Manufacturing Technology Management, Vol. 22 No. 4, pp. 506-526.

[20]. Romano, P., (2009), "How can fluid dynamics help supply chain management?" International Journal of Production Economics, Vol. 118 No. 2009, pp. 463-72.

[21]. Sakun Boon-itt and Chee Yew Wong, (2011), "The moderating effects of technological and demand uncertainties on the relationship between supply chain integration and customer delivery performance", International Journal of Physical Distribution \& Logistics Management, Vol. 41 No. 3, pp. 253-276.

[22]. Soo Wook Kim (2006), "The effect of supply chain integration on the alignment between corporate competitive capability and supply chain operational capability", International Journal of Operations \& Production Management, Vol. 26 No. 6, pp. $1084-1107$.

[23]. Stevenson M. and M. Spring, (2007), "Flexibility from a supply chain perspective: definition and review", International Journal of Operations \& Production Management, Vol. 27 No. 7, pp. 685-713.

[24]. Supply Chain Flexisibility", Industrial Management and Data systems, Vol. 103 No. 6. Pp. 446-456.

[25]. Towill D.R. and P. Childerhouse (2011), "Industrial engineering priorities for improved demand chain performance", International Journal of Productivity and Performance Management, Vol. 60 No. 3, pp. 202-221

[26]. Van Der Vaart, T. and Van Donk, D.P., (2008), “A critical review of survey-based research in supply chain integration", International Journal of Production Economics, Vol. 111 No. 1, pp. 42-55.

[27]. Vijay R. Kannan \& Keah Choon Tan (2010), "Supply chain integration: cluster analysis of the impact of span of integration", Supply Chain Management: An International Journal, Vol. 15 No. 3, pp. 207-215 